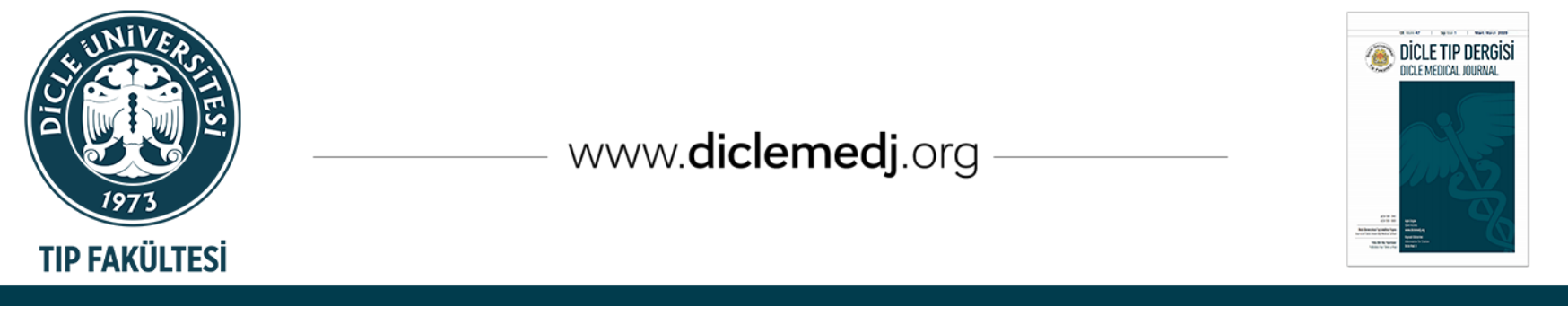

\title{
Multipl Sklerozisli Hastalarda Serum sFas, sFas Ligand Düzeyleri ile FAS ve FASLG Polimorfizmleri Arasındaki İlişkinin Araştırılması
}

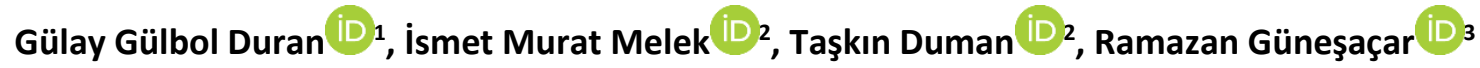 \\ 1 Hatay Mustafa Kemal Üniversitesi Tıp Fakültesi Tıbbi Biyoloji Anabilim Dalı Hatay, Türkiye \\ 2 Hatay Mustafa Kemal Üniversitesi Tıp Fakültesi Nöroloji Anabilim Dalı Hatay, Türkiye
}

3 Alanya Alaaddin Keykubat Üniversitesi Tıp Fakültesi Tıbbi Biyoloji Anabilim Dalı Antalya, Türkiye

Geliş: 05.11.2019; Revizyon: 24.03.2020; Kabul Tarihi: 08.04.2020

Öz

Amaç: Multiple Sklerozis (MS) otoreaktif T lenfositlerin miyelin antijenlerine karşı gösterdiği reaksiyon sonucu ortaya çıkan otoimmün bir hastalıktır. Fas-FasL yolağı $\mathrm{T}$ hücre apoptozisinde önemli bir rol oynamaktadır ve otoimmun hastalıklarda Fas-FasL yolağında defektler olduğu bilinmektedir. Bu çalışmada FAS -670 A/G ve FASLG -844 T/C fonksiyonel gen polimorfizmleri ile serum sFas ve sFasL düzeylerinin MS gelişimine ve hastalı̆̆ın patogenezine katkısının araştırılması amaçlanmıştır.

Yöntemler: Çalışmaya 108 MS hastası ve kontrol grubu olarak da 98 sağlıklı birey dahil edilmiştir. FAS -670 A/G ve FASLG -844 T/C polimorfizmlerinin belirlenmesi için PCR-RFLP tekniği kullanılmıştır. sFas ve sFasL düzeyleri solid fazlı sandviç ELISA kiti kullanılarak ölçülmüştür.

Bulgular: MS hastalarında FAS -670 AG genotipi frekansı $(\% 55,55)$ sağlıklı kontrollere $(\% 72,44)$ göre düşük $(\mathrm{p}=0.014)$, GG genotipi frekansı ise hasta grubunda $(\% 19,44)$ sağlıklı kontrollere $(\% 3,06)$ göre anlamlı derecede yüksek bulundu (p $=0.0001)$. Hasta ve kontrol grupları arasında FASLG -844 T/C polimorfizmi açısından anlamlı bir fark bulunamadı (p > 0.05). Serum sFasL düzeyleri MS grubunda, sağlıklı kontrol grubuna göre istatistiksel olarak anlamlı bir şekilde yüksek bulunmakla $(p=0.015)$ birlikte, sFas düzeyleri gruplar arasında benzer bulundu $(p=0.705)$. FAS - FASLG polimorfizmleri ile serum sFas - sFasL düzeyleri arasında anlamlı bir ilişki bulunamadı.

Sonuç: Sonuçlarımız FAS -670 AG genotipinin MS riskini azaltarak ( $R R=0.475, p=0.014$ ) koruyucu bir rol oynayabileceğini, GG genotipinin ise MS ile ilişkili güçlü bir risk faktörü $(R R=7.644, p=0.0001$ ) olabileceğini, serum sFasL düzeylerindeki artışın ise bu faktörün MS patogenezine katkı sunabileceğini gösterebilir.

DOI: 10.5798/dicletip.755730

Correspondence / Yazışma Adresi: Ramazan Güneşaçar, Alanya Alaaddin Keykubat Üniversitesi Tıp Fakültesi Tıbbi Biyoloji Anabilim Dalı, Alanya/ Antalya, Türkiye e-mail: rgunesacar@hotmail.com 
Anahtar kelimeler: Multiple Sklerozis (MS), Fas, Fas Ligand, PCR-RFLP

\title{
Investigation of the Relationship Between Serum Solubl Fas (sFas), Soluble Fas Ligand (sFasL) Levels and FAS-FASLG Polymorphisms in Patients with Multiple Sclerosis
}

\begin{abstract}
Objective: Multiple Sclerosis (MS) is an autoimmune disease caused by the reaction of autoreactive T lymphocytes to myelin antigens. Fas-FasL patway plays an important role in T cell apoptosis and It is well known that there are defects in the Fas-FasL pathway in autoimmune diseases. In this study, we aimed to investigate the effect of FAS -670 A/G and FASLG -844 T/C functional gene polymorphisms and serum sFas and sFasL levels on MS development and their contribution to the pathogenesis of the disease.

Methods: 108 MS patients and 98 healthy individuals as control group were included in the study. PCR-RFLP technique was used to determine FAS $-670 \mathrm{~A} / \mathrm{G}$ and FASLG -844 T/C polymorphisms. Serum sFas and sFasL levels was measured using the solid phase sandwich ELISA kit.

Results: FAS -670 AG genotype frequency in MS patients was lower than healthy controls ( $p=0.014)$, while GG genotype frequency was significantly higher in the patient group than healthy controls $(p=0.0001)$. Serum sFasL levels were significantly higher in MS group compared to healthy controls $(\mathrm{p}=0.015)$, but $\mathrm{sFas}$ levels were similar between the groups $(\mathrm{p}=0.705)$. There was no significant correlation between FAS - FASLG polymorphisms and sFas - sFasL levels.

Conclusion: Our results suggest that FAS -670 AG genotype may play a protective role by reducing the risk $(0 R=0.475$, $p=0.014)$, while the GG genotype is a strong risk factor associated with MS (OR=7.644, $\mathrm{p}=0.0001)$, and elevated levels of serum sFasL may contribute to the pathogenesis of the disease.
\end{abstract}

Keywords: Multiple Sclerosis (MS), Fas, Fas Ligand, PCR-RFLP

\section{GíRiş}

Son yllardaki çalışmalar Multiple sklerozis (MS)'in otoreaktif $\mathrm{T}$ lenfositlerin miyelin antijenlerine karşı gösterdiği reaksiyon sonucu ortaya çıkan otoimmün inflamatuvar bir hastalık olduğunu hipotezini destekler niteliktedir. $\mathrm{Bu}$ hipotez özellikle deneysel alerjik ensefalomiyelit ve MS'deki hayvan modelleri ile desteklenmektedir ${ }^{1}$. Tümör nekroz faktör süper ailesinin bir üyesi olan ve hedef hücrelerde apoptozu başlatan Fas (Apo-1, CD95), $45 \mathrm{kDa}$ moleküler ağırlığa sahip tip1 membran proteinidir. Çeşitli hücre ve dokularda eksprese edilmekle birlikte en fazla eksprese edildikleri hücre tipi aktive lenfositlerdir ${ }^{1-5}$. Fas, birçok hücre tipinde apoptoz sinyalinde merkezi rol oynamaktadır6. Fas reseptörünün ligandı (Fas ligand, FasL) 40 $\mathrm{kDa}$ büyüklügünde olup dolaşımda dimer ya da trimer şeklinde bulunur ${ }^{5}$. Reseptör-ligand, FasFasL, birçok fizyolojik süreçte apoptozisin primer mediyatörüdür7 ${ }^{7}$.
FasL'ın hücre yüzeyindeki Fas reseptörüne bağlanmasıyla sitoplazmaya Kaspaz-8'i aktive eden sinyaller yayılır. Kimyasal, fiziksel ya da viral enfeksiyonlarla hasar görmüş hücrelerde, interlökin-1 (IL-1) gibi pro-inflamatuar sitokinlerin etkisi ile hücre yüzeyinde Fas ekspresyonu başlar. Bu süreç Fas antijeninin up-regülasyonu olarak adlandırılır. $\mathrm{Bu}$ olay esnasında sitotoksik T hücreleri de FasL yapımı için uyarılırlar ve FADD (Fas ile ilişkili ölüm domaini) aracılığıyla oluşan Fas-FasL bağlanması sonucu prokaspaz 8'in aktivasyonu sağlanarak hücrenin apoptozise gitmesi indüklenmiş olur ${ }^{8,9}$.

Fas aracılı apoptosis sayesinde immün yanıt sonucu oluşan aktive $\mathrm{T}$ hücreleri ortamdan uzaklaştırılarak otoimmün reaksiyonlar önlenmektedir. Otoimmun hastalıklarda Fas yolağında defektler ve Fas seviyelerinde artışlar saptanmıştı́r ${ }^{10,11}$.

Fas geni (FAS) 10. kromozomun kisa kolu üzerinde lokalize olup 9 ekzon ve 8 introndan ibarettir. FasL geni (FASLG) ise 1. kromozomda 
bulunmakta ve 4 ekzon 3 intron içermektedir ${ }^{12}$. Her iki gende de çok sayıda polimorfizm saptanmıştır. Huang ve ark. tarafından tanımlanmış olan FAS geninin 5' promotor bölgesindeki $-670 \quad \mathrm{~A} / \mathrm{G}$ tek nükleotid polimorfizmi bir A/G transisyonudur. FAS -670 A/G polimorfizmi gama interferon aktivasyon bölgesinde (GAS) yer alır. Bu bölge sinyal dönüștürücü ve transkripsiyon aktivatörleri (signal transducers and activator of transcription, STAT) gibi transkripsiyon faktörlerine bağlanarak FAS transkripsiyonunu etkilemektedir ${ }^{13-15}$.

Bazı çalışmalarda FAS -670 G allelinin FAS ekspresyonunu azalttığı bildirilmiștiri6-18. FASLG promoter bölgesindeki $-844 \quad \mathrm{~T} / \mathrm{C}$ fonksiyonel polimorfizmi de CAAT/enhancer binding protein beta olarak isimlendirilen diğer bir transkripsiyon faktörünün bağlanma bölgesinde yer almaktadır. C allelinin, $\mathrm{T}$ allelinden daha yüksek bazal transkripsiyon aktivitesine sahip olduğu gösterilmiștir ${ }^{19}$.

Literatürde MS hastalarında FAS ve FASLG polimorfizmi ile ilgili çalışma sayısı oldukça sınırlıdır. Aynı zamanda çeşitli etnik gruplarda yapılan çalışmalar arasında da çelişkili sonuçlar bulunmaktadır. Bazı çalışmalarda FAS -670 A/G polimorfizmi ile MS arasında ilişki saptanırken 12,20-21, bazı çalışmalarda ilişki bulunamamıștır ${ }^{22,23}$. FASLG promoter bölgesinde meydana gelen -844 T/C polimorfizmi ile MS arasındaki ilişkiye işaret eden sadece bir tek çalışma mevcuttur ve bu çalışmada FASLG -844 T/C polimorfizmi ile MS arasında ilişki bulunamamıştır ${ }^{23}$.

Ayrıca, Türk MS hastalarında FAS ve FASLG polimorfizmleri ile serum soluble Fas (sFas) ve soluble Fas Ligand (sFasL) seviyelerini gösteren bir çalışma mevcut değildir. $\mathrm{Bu}$ nedenle çalışmamızda FAS -670 A/G ve FASLG -844 T/C fonksiyonel gen polimorfizmleri ile serum sFas ve sFasL düzeylerinin MS gelişimine etkisi ve hastalığın immünopatogenezindeki rolünü araştırmayı amaçladık.

\section{YÖNTEMLER}

Çalışmaya Hatay Mustafa Kemal Üniversitesi Tıp Fakültesi Nöroloji Anabilim Dalına başvuran, aralarında akrabalık ilişkisi bulunmayan 108 MS hastası (40 erkek, 68 kadın, ortalama yaş $\pm S D=44.86 \pm 13.57$ yll) ile, ailesinde MS öyküsü bulunmayan 98 sağlıklı birey (44 erkek, 54 kadın, ortalama yaş \pm SD = $40.49 \pm 11.21$ yll ) dahil edildi. Çalışmamız Hatay Mustafa Kemal Üniversitesi Tıp Fakültesi Etik Kurulu tarafindan onaylandı (Etik Kurul No: 2019/59) ve çalışmanın bütünü Helsinki Deklarasyonu yönergelerine uygun şekilde gerçekleştirildi.

Çalışmaya dahil edilen tüm hasta ve sağlıklı kontrollerden EDTA'lı tüplere $2 \mathrm{ml}$ tam kan alındı ve genomik DNA örnekleri ticari olarak temin edilen DNA ekstraksiyon kiti (RTA, Türkiye) kullanılarak üretici firmanın protokolüne göre elde edildi.

FAS $\quad-670 \quad$ A/G ve FASLG $-844 \quad$ T/C polimorfizmlerinin belirlenmesi için PCR-RFLP tekniği kullanıldı. FAS $-670 \mathrm{~A} / \mathrm{G}$ polimorfizmini saptamak için sırasıyla forward ve reverse primerler; F:5'-CTA CCT AAG AGC TAT CTA CCG TTC-3', R: 5'-GGC TGT CCA TGT TGT GGC TGC3', FASLG -844 T/C polimorfizmini saptamak için ise sırasıyla forward ve reverse primerler; F: 5'-CAG CTA CTC GGA GGC CAA G-3', R: 5' - GCT CTG AGG GGA GAG ACC AT-3' kullanıldı. Her iki gen bölgesi için, PCR reaksiyonu: 50 ng genomik DNA, $1.5 \mathrm{mM} \mathrm{MgCl2} \mathrm{(Fermentas),} \mathrm{10X} \mathrm{PCR}$ tamponu (Fermentas), her bir primerden 5 pmol, 0,2 mM dNTP karışımı (Fermentas) ve $1 \mathrm{U}$ Taq polimeraz (Fermentas) içeren total $50 \mathrm{ul}$ hacim olmak üzere hazırlandı. FAS için aplifikasyon döngüleri; $94{ }^{\circ} C^{\prime}$ de 3 dakika ön denatürasyon basamağından sonra her bir döngü $94^{\circ} \mathrm{C}$ 'de 1 dakika, $58^{\circ} \mathrm{C}$ 'de 1 dakika ve 72 ${ }^{\circ} \mathrm{C}$ 'de 2 dakika içeren 40 döngü olarak tekrarlandı, ardından $72{ }^{\circ} \mathrm{C}$ 'de 10 dakika olarak gerçekleștirildi. FASLG için aplifikasyon döngüleri; $94{ }^{\circ}{ }^{\prime}$ 'de 2 dakika ön denatürasyon basamağından sonra her bir döngü $94{ }^{\circ} \mathrm{C}$ 'de 30 
saniye, $62^{\circ} \mathrm{C}$ 'de 45 saniye ve $72^{\circ} \mathrm{C}$ 'de 45 saniye içeren 35 döngü olarak tekrarlandı, ardından 72 ${ }^{\circ} \mathrm{C}$ 'de 7 dakika olarak gerçekleștirildi. PCR ürünleri oda sıcaklığında, agaroz jel elektroforez tekniği ile \%2'lik agaroz jelde 150 V'da 30-35 dakika süresince yürütüldü ve UV görüntüleme sistemi (Wealtec, Dolphin-View, ABD) ile bant oluşumları (FAS: 332 bç, FASLG: $401 \mathrm{bç)}$ incelendi.

PCR ürünleri, FAS -670 A/G polimorfizmlerini saptamak için $5 \mathrm{U}$ MvaI restriksiyon enzimi ile $37{ }^{\circ} \mathrm{C}$ 'de, FASLG -844 T/C polimorfizmlerini saptamak için ise $5 \mathrm{U}$ BsrDI restriksiyon enzimi ile $55{ }^{\circ} \mathrm{C}$ 'de bir gece inkübe edildi. İnkübasyon sonunda $80{ }^{\circ} \mathrm{C}$ 'de 20 dakika bekletilerek restriksiyon enzimleri inaktive edildi. Kesim ürünleri oda sıcaklığında, \%3'lük agaroz jelde 150 V'da 30-35 dakika elektroforeze tabi tutuldu ve UV görüntüleme sistemi (Wealtec, Dolphin-View, ABD) ile RFLP bant oluşumları incelendi. FAS geni için MvaI ile inkübasyona bırakılan 332 baz çiftlik PCR ürününün genotiplere göre farklı büyüklüklerde bant (AA: 233, 99 bç, GG: 189, 99, 44 bç, AG: 233, 189, 99 , $44 \mathrm{bç)}$ oluşturduğu gözlendi (Resim 1). FASLG için ise BsrDI ile inkübasyona bırakılan $401 \mathrm{baz}$ çiftlik PCR ürününün genotiplere göre farklı büyüklüklerde bant (TT: 401 bç, CC: 233, 168 bç, TC: 401, 233, 168 bç) oluşturduğu gözlendi (Resim 2).

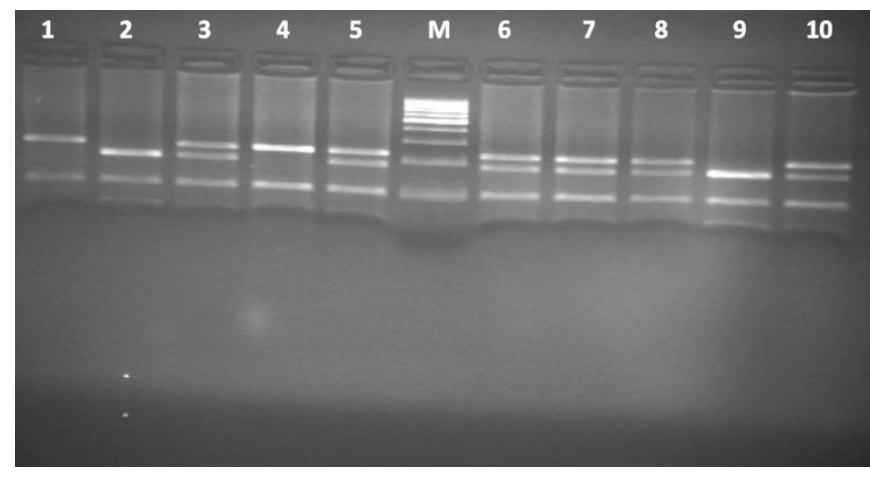

Resim 1. FAS -670 A/G polimorfizmine ait jel görüntüsü (Marker 100 bç): 1 ve 4. sıra: AA Genotipi $(233,99$ bç); $3,5,6,7,8$ ve 10 . sıra: AG Genotipi $(233,189,99,44$ bç); 2 ve 9. sıra: GG Genotipi $(189,99,44$ bç $)$

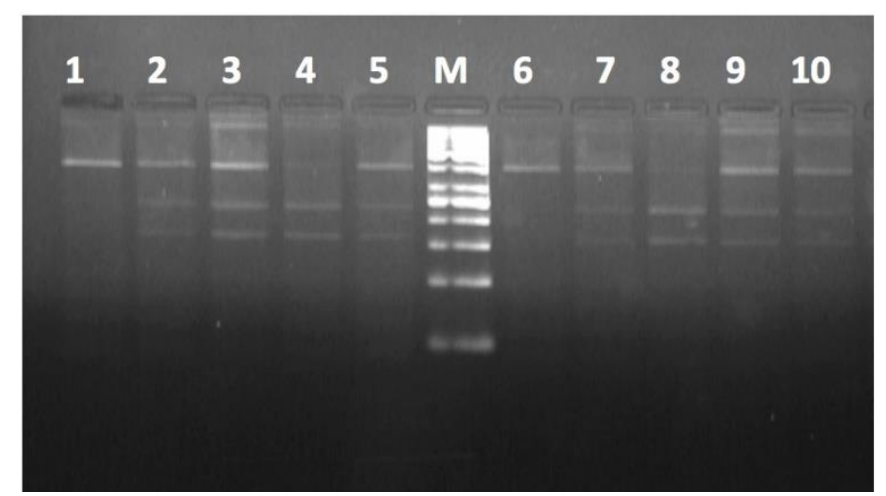

Resim 2. FASLG -844 T/C polimorfizmine ait jel görüntüsü (Marker 50 bç): 1ve 6.sıra: TT Genotipi (401 bç); 2,3,5,7,9 ve 10. sıra: TC Genotipi (401, 233,168 bç); 4 ve 8. sıra: CC Genotipi $(233,168$ bç).

Serum soluble Fas ve soluble Fas Ligand düzeyleri, hasta grubu içinden randomize olarak seçilen 33 MS hastası ile kontrol grubundan randomize seçilen 50 sağlkklı kontrolde, solid fazlı sandviç ELISA kiti kullanılarak (Bender Medsystems Diagnostics $\mathrm{GmbH}$, Avusturya) üretici firmanın talimatları doğrultusunda ölçüldü. Bunun için hasta ve kontrollerden standart biyokimya tüplerine 5 ml venöz kan alınarak soğutmalı santrifüjde 400 g'de 10 dakika santrijüf edildi ve elde edilen serum örnekleri porsiyonlara bölünerek çalıșma gününe kadar -80 0C'de muhafaza edildi.

Çalışılan polimorfizmlerin genotip frekansları, Hardy-Weinberg dengesi için Ki-kare testi ile test edildi. Genotip ve allel frekanslarının dağılımı Fischer Exact Test, serum sFas ve sFasL değerleri arasındaki farklar Student $\mathrm{T}$ testi ve polimorfizmler ile serum düzeyleri arasındaki farklar Mann-Whitney U testi ile değerlendirildi.

\section{BULGULAR}

Çalışılan polimorfizmlerin genotip ve alel frekanslarının hem MS, hem de kontrol grubunda Hardy-Weinberg dengesine uygun olduğu görüldü ( $p>0.05$ ). Tablo I'de gösterildiği gibi, MS hastalarında FAS -670 AG genotipi frekansı (\%55.55) sağlıklı kontrollere $(\% 72,44)$ göre düşük (RR $=0.475, \% 95 \mathrm{GA}=0.265-0.852$, $\mathrm{p}=0.014)$, GG genotipi frekansı ise hasta 
grubunda $(\% 19,44)$ sağlıklı kontrollere $(\% 3,06)$ göre anlamlı derecede yüksek bulundu $(\mathrm{RR}=7.644, \% 95 \mathrm{GA}=$ 2.203-26.524, $\mathrm{p}=0.0001)$. Hasta ve kontrol grupları arasında $670 \mathrm{G}$ alleli sıklığı istatistiksel olarak anlamsızdı $(\mathrm{RR}=1.383, \% 95 \mathrm{GA}=0.935-2.046, \mathrm{p}=0.112)$. Gruplar arasında FASLG -844 TC ve CC genotipi ile $C$ alleli sıklığı açısından da istatistiksel olarak anlamlı bir fark bulunamadı (Tablo I).

Tablo I: Hasta ve kontrol gruplarında FAS -670 A/G ve FASLG $844 \mathrm{~T} / \mathrm{C}$ polimorfizmlerinin genotip dağılımı ve allel frekansları

\begin{tabular}{|c|c|c|c|c|c|}
\hline $\begin{array}{l}\text { FAS } \quad-670 \\
\text { A/G Genotip } \\
\text { Dağılımı }\end{array}$ & $\begin{array}{l}\text { Hasta } \\
(n=108)\end{array}$ & $\begin{array}{l}\text { Kontrol } \\
(n=98)\end{array}$ & $\mathrm{X} 2$ & RR (\%95 GA) & P değeri \\
\hline AA & $27(\% 25,00)$ & $\begin{array}{l}24 \\
(\% 24,49)\end{array}$ & 0.007 & $\begin{array}{l}1,028(0.545- \\
1.937)\end{array}$ & Referans \\
\hline$A G$ & $60(\% 55,55)$ & $\begin{array}{l}71 \\
(\% 72,44)\end{array}$ & 6.333 & $\begin{array}{l}0.475(0.265- \\
0.852)\end{array}$ & 0.014 \\
\hline GG & $21(\% 19,44)$ & $3(\% 3,06)$ & 13.398 & $\begin{array}{l}7.644(2.203- \\
26.524)\end{array}$ & 0.0001 \\
\hline \multicolumn{6}{|l|}{ Allel frekansı } \\
\hline A & $\begin{array}{l}114 \\
(\% 52,78)\end{array}$ & $\begin{array}{l}119 \\
(\% 60,71)\end{array}$ & 2.634 & $\begin{array}{l}0.723(0.489- \\
1.070)\end{array}$ & Referans \\
\hline G & $\begin{array}{l}102 \\
(\% 47,22)\end{array}$ & $\begin{array}{l}77 \\
(\% 39,29)\end{array}$ & 2.634 & $\begin{array}{l}1.383(0.935- \\
2.046)\end{array}$ & 0.112 \\
\hline \multicolumn{6}{|l|}{$\begin{array}{l}\text { FASLG -844 } \\
\text { T/C Genotip } \\
\text { Dağılımı }\end{array}$} \\
\hline TT & $34(\% 31,48)$ & $\begin{array}{l}23 \\
(\% 23,47)\end{array}$ & 1.648 & $\begin{array}{l}1.498(0.807- \\
2.782)\end{array}$ & Referans \\
\hline TC & $54(\% 50,00)$ & $\begin{array}{l}62 \\
(\% 62,26)\end{array}$ & 3.675 & $\begin{array}{l}0.581(0.332- \\
1.014)\end{array}$ & 0.068 \\
\hline $\mathrm{CC}$ & $20(\% 18,52)$ & $\begin{array}{l}13 \\
(\% 13,26)\end{array}$ & 1.054 & $\begin{array}{l}1.486(0.696- \\
3.175)\end{array}$ & 0.345 \\
\hline \multicolumn{6}{|l|}{ Allel frekansı } \\
\hline$T$ & $\begin{array}{l}122 \\
(\% 56,48)\end{array}$ & $\begin{array}{l}108 \\
(\% 55,10)\end{array}$ & 0.079 & $\begin{array}{l}1.058(0.716- \\
1.561)\end{array}$ & Referans \\
\hline C & $\begin{array}{l}94 \\
(\% 43,52)\end{array}$ & $\begin{array}{l}88 \\
(\% 44,90)\end{array}$ & 0.079 & $\begin{array}{l}0.946(0.641- \\
1.396)\end{array}$ & 0.843 \\
\hline
\end{tabular}

RR: Rölatifrisk, GA: Güven aralığı, FAS: Hücre yüzey ölüm resptörü geni, FASLG: FAS ligand geni

Serum sFasL düzeyleri MS grubunda $0.56 \pm$ $0.20 \mathrm{ng} / \mathrm{ml})$, sağlıklı kontrol grubuna (0.46 \pm $0.13 \mathrm{ng} / \mathrm{ml}$ ) göre istatistiksel olarak anlamlı bir şekilde yüksek bulundu ( $\mathrm{p}=0.015)$, ancak sFas düzeyleri hasta grubunda (75.51 \pm 32.53 $\mathrm{pg} / \mathrm{ml})$, kontrol grubuna göre (79.22 \pm 49.64 $\mathrm{pg} / \mathrm{ml})$ istatistiksel olarak anlamlı değildi $(\mathrm{p}=$
0.705), (Tablo II). Ayrıca, çalıșılan FAS ve FASLG polimorfizmleri ile serum sFas ve sFasL düzeyleri arasında da anlamlı bir ilişki saptanamadı (Tablo III).

Tablo II: Hasta ve kontrol gruplarında sFas ve sFasL düzeylerinin karşılaştırılması

\begin{tabular}{|c|c|c|}
\hline & $\begin{array}{c}\text { sFas (pg/ml) } \\
\text { (Ortalama } \pm \text { Standart } \\
\text { sapma) }\end{array}$ & $\begin{array}{c}\text { sFasL }(\mathrm{ng} / \mathrm{ml}) \\
\text { (Ortalama } \pm \\
\text { Standart sapma) }\end{array}$ \\
\hline $\begin{array}{ll}\text { Multiple } & \text { sklerosis } \\
(\mathrm{n}=33) & \end{array}$ & $75.51 \pm 32.53$ & $0.56 \pm 0.20$ \\
\hline Kontrol ( $n=55)$ & $79.22 \pm 49.64$ & $0.46 \pm 0.13$ \\
\hline P değeri & 0.705 & 0.015 \\
\hline
\end{tabular}

sFas: Çözünebilir formda Fas proteini, sFasL: Çözünebilir formda Fas Ligand proteini

Tablo III: FAS -670 A/G ve FASLG -844 T/C genotiplerine göre serum sFas ve sFasL düzeyleri

\begin{tabular}{|c|c|c|c|c|}
\hline $\begin{array}{l}\text { FAS } \\
\text { Genotipleri }\end{array}$ & -670 & $\begin{array}{l}\text { Multiple sklerosis } \\
\qquad(\mathrm{n}=33)\end{array}$ & $\begin{array}{l}\text { Kontrol } \\
(n=50)\end{array}$ & \\
\hline AA & & $80.88 \pm 40.00$ & $83.06 \pm 21.57$ & sFas (pg/ml) \\
\hline$A G+G G$ & & $74.07 \pm 30.99$ & $78.60 \pm 52.90$ & $\begin{array}{c}\text { (Ortalama } \pm \\
\text { Standart sapma) }\end{array}$ \\
\hline$P$ değeri & & 0.912 & 0.167 & \\
\hline $\begin{array}{l}\text { FASLG } \\
\text { Genotipleri }\end{array}$ & -844 & & & \\
\hline TT & & $0.52 \pm 0.08$ & $0.53 \pm 0.26$ & sFasL (ng/ml) \\
\hline $\mathrm{TC}+\mathrm{CC}$ & & $0.57 \pm 0.23$ & $0.44 \pm 0.04$ & $\begin{array}{c}\text { (Ortalama } \pm \\
\text { Standart sapma) }\end{array}$ \\
\hline$P$ değeri & & 0.984 & 0.158 & \\
\hline
\end{tabular}

\section{TARTIŞMA}

Multipl skleroz (MS) aksonal hasara yol açan çok odaklı ve geçici olarak dağılmış merkezi sinir sistemi hasarı ile karakterize, otoimmün kaynaklı kronik inflamatuvar ve demiyelinizan bir hastalıktır ${ }^{24}$. Demiyelinizasyondan otolitik 
lenfositler ve makrofajların da dahil olduğu inflamatuvar hücrelerin sorumlu olduğu düşünülmektedir ${ }^{1}$.

Programlanmış hücre ölümü olarak tanımlanan apoptoz hücre döngüsü, immün sistemin normal gelişimi ve işleyiş̧i, hormona bağlı atrofi, embriyonik gelişim ve kimyasal kaynaklı hücre ölümü gibi çeşitli işlemlerin hayati bir bileșeni olarak kabul edilir. Kusurlu apoptoz nörodejeneratif hastalıklar, iskemik hasar, otoimmün hastalıklar ve çeşitli kanser türleri gibi birçok hastalığın patofizyolojisinde yer almaktadır8.

Fas ve FasL, hücre ölümünün düzenlenmesinde rol oynayan iki molekül olup etkileşimleri $\mathrm{T}$ hücre reseptör (TCR) genlerini doğru şekilde düzenleyemeyen timositlerin apoptozuna ve negatif seleksiyon olarak adlandırılan bir işlem olan kendi antijenlerini yabancı olarak tanıyan hücrelerin apoptozisine neden olur ${ }^{1}$.

Literatürde birkaç etnik gruba dahil MS hastalarında FAS ve FASLG polimorfizmleri ile ilgili sınırlı sayıda çalışma mevcut olup yapılan çalışmalar arasında çelişkili sonuçlar bulunmaktadır. Bazı çalışmalarda FAS -670 A/G polimorfizmi ile MS arasında ilişki saptanırken ${ }^{12,20,21}$ bazı çalışmalarda ise ilişki bulunamamıştır 22,23 .

Kantarcı ve arkadaşları, MS hastalarında Fas ile indüklenen hücre ölüm mekanizmasında bozukluklar olabileceği, FAS -670 polimorfizminin kadınlarda MS yatkınlığı ile ilişkili olduğunu bildirmişlerdir ${ }^{12}$. Hollanda'da 382 MS hastası ve 206 sağlıklı gönüllünün dahil edildiği bir başka çalışmada, FAS -670 G allel taşıyıcilığının hastalarda kontrollere göre anlamlı derecede düşük olduğu, bu polimorfizm ile klinik özellikler arasında bir ilişki saptanamamasından dolayı ise FAS -670 G taşıyıcılığının MS gelişme riskini azalttığı, ancak hastalığın seyrini etkilemediği sonucuna varılmıştır ${ }^{20}$. Huang ve arkadaşları ise FAS promotör bölgesi polimorfizmlerinin MS duyarlılığında olası bir etkisi olabileceğini bildirmişlerdir ${ }^{21}$. FAS -670 polimorfizminin MS ile ilişsisini bildiren bu çalışmaların yanı sıra, literatürde aynı polimorfizmin hastalıkla ilişkili olmadığını bildiren çalışmalar da mevcuttur. Japon popülasyonunda yapılan bir çalışmada bu polimorfizmin MS'e duyarlılığa herhangi bir katkısı olduğuna dair bir kanıt bulunamadığı bildirilmiştir ${ }^{22}$. İran popülasyonunda yapılan bir çalışmada da FAS -670 GG genotipinin sekonder ilerleyici MS tipi ile sinırda artan bir sıklığı belirtilse de FAS -670 polimorfizmi ile MS hastaları arasında istatistiksel bir ilișki saptanamamıştır ${ }^{23}$. Çalışmamızda, MS hastalarında FAS -670 AG genotipi dağılımının kontrol grubuna göre düşük $(\mathrm{RR}=0.475, \% 95$ $\mathrm{GA}=0.265-0.852, \mathrm{p}=0.014), \mathrm{GG}$ genotipi dağılımının ise oldukça anlamlı bir şekilde yüksek olduğunu saptadık (RR $=7.644, \% 95 \mathrm{GA}$ $=2.203-26.524, p=0.0001$ ). Sonuçlarımız, FAS -670 AG genotipinin MS riskini azaltarak potansiyel koruyucu rolünü, GG genotipinin ise MS için potansiyel bir risk faktörü olabileceğini göstermektedir.

Literatürde FASLG -844 T/C gen polimorfizmi ile MS arasındaki ilişkiye işaret eden bir tek çalışma mevcut olup bu çalışmada FASLG -844 T/C polimorfizmi ile MS arasında ilişki bulunamamıştır ${ }^{23}$. Benzer olarak, çalışmamızda da hasta ve kontrol grupları arasinda FASLG $844 \mathrm{~T} / \mathrm{C}$ polimorfizmi açısından fark bulunamaması Türk popülasyonunda FASLG $844 \mathrm{~T} / \mathrm{C}$ polimorfizminin MS hastalığı ile ilişkisinin olmadığını gösterebilir.

Literatürde serum sFas ve $s F a s ~ L$ düzeylerinin MS hastalı̆̆ çalışmalar arasında da çelişkili sonuçlar bulunmaktadır. Bazı çalışmalarda sFas ve sFasL düzeyleri ile MS arasında ilişki saptanırken ${ }^{25,26}$, bazı çalışmalarda ise ilişki bulunamamışı ır ${ }^{27,28}$. Çalışmamızda hasta ve kontrol grupları arasında sFas düzeyleri benzer bulunmuștur. Zipp ve arkadaşları, MS hastalarında serum sFas seviyelerinin sağlıklı kontrollere göre arttığını 
göstermişlerdir ${ }^{25}$. Moreno ve arkadaşları ise sFas ve sFasL serum seviyelerinin MS ve kontrol grubunda farklı olmadığını bildirmişlerdir ${ }^{27}$.

Çalışmamızda sFas düzeylerinin hasta ve kontrol gruplarında benzerlik gösterdiğini $(\mathrm{p}=$ 0.705), ancak sFasL düzeylerinin hasta grubunda, kontrol grubuna kıyasla artmış olduğunu ( $\mathrm{p}=0.015)$ belirledik. Serum düzeylerinin hasta ve kontrol gruplarında genotiplere göre dağılımları arasında da anlamlı bir fark saptayamadık. Bu nedenle, artmış sFasL düzeylerinin genotip ve allel frekansları ile ilişkilendirilememesi, hastalarda serum sFasL düzey artışının FASLG $-844 \quad \mathrm{~T} / \mathrm{C}$ polimorfizminden kaynaklanmadığını, ancak serum sFasL düzeylerindeki artışın MS patogenezine katkısı olabileceğini düşündürmektedir.

Polimorfizm ve allel frekansları için 108 hasta ve 98 kontrolün dahil edildiği çalışmamızda, bütçe kısıtlılıkları nedeniyle ELISA analizlerine 33 hasta ve 55 kontrol dahil edilmiștir. Tüm hasta ve kontrollerin serum protein düzeylerinin ölçülememesi çalışmamızın başlıca limitasyonudur. Gelecekte daha geniş popülasyonda ELISA analizlerinin yapılmasının, sFas ve sFasL düzeylerinin MS patogenezine katkısının anlaşılması bakımından yararlı olabileceğini düşünmekteyiz.

Sonuç olarak, FAS -670 AG genotipinin MS riskini azaltarak koruyucu bir rol oynayabileceğini (RR $=0.475, \mathrm{p}=0.014)$, GG genotipinin ise MS ile ilişkili güçlü bir risk faktörü olduğunu ( $R R=7.644, p=0.0001)$, serum sFasL düzeylerindeki artışın ise hastalığın immunopatogenezine katkısını gösterebilir.

Etik Kurul Kararı: Çalışmamız Hatay Mustafa Kemal Üniversitesi Tıp Fakültesi Etik Kurulu tarafindan onaylandı (Etik Kurul No: 2019/59) ve çalışmanın bütünü Helsinki Deklarasyonu yönergelerine uygun şekilde gerçekleştirildi.
Çıkar Çatışması Beyanı: Yazarlar çıkar çatışması olmadığını bildirmişlerdir.

Finansal Destek: Bu çalışma her hangi bir fon tarafından desteklenmemiştir.

Declaration of Conflicting Interests: The authors declare that they have no conflict of interest.

Financial Disclosure: No financial support was received.

\section{KAYNAKLAR}

1. Volpe E, Sambucci M, Battistini L, Borsellino G. Fas-Fas Ligand: Checkpoint of $\mathrm{T}$ Cell Functions in Multiple Sclerosis. Front Immunol. 2016; 7: 382.

2. Mohammadzadeh A, Pourfathollah AA, Sahraian MA, et al. Evaluation of apoptosisrelated genes: Fas (CD94), FasL (CD178) and TRAIL polymorphisms in Iranian multiple sclerosis patients. J Neurol Sci. 2012; 312: 1669.

3. Xia B, Yu HY, Guo QS, et al. Association of Fas670 gene polymorphism with inflammatory bowel disease in Chinese patients. World J Gastroenterol. 2005; 11: 415-17.

4. Kim KM, Lee K, Hong YS, Park HY. Fasmediated apoptosis and expression of related genes in human malignant hematopoietic cells. Exp Mol Med. 2000; 32: 246-54.

5. Kischkel FC, Hellbardt S, Behrmann I, et al. Cytotoxicity-dependent APO-1 (Fas/CD95)associated proteins form a death-inducing signaling complex (DISC) with the receptor. EMBO J. 1995; 14: 5579-88.

6. Gilhar A, Yaniv R, Assy B, et al. Fas pulls the trigger on psoriasis. Am J Pathol. 2006; 168: 170-5.

7. Jalali SA, Shandiz HF, Afshari JT, et al. Status of FAS and FAS Ligand Gene Polymorphisms in Patient with Breast Cancer in Northeastern IRAN. Rep Biochem Mol Biol. 2018; 7: 23-29. 
8. Elmore S. Apoptosis: A Review of Programmed Cell Death. Toxicol Pathol. 2007; 35: 495-516.

9. Nagata S, Golstein P. The Fas death factor. Science 1995; 267: 1449-56.

10. Meynier S, Rieux-Laucat F. FAS and RAS related Apoptosis defects: From outoimmunity to leukemia. Immunol Rev, 2019; 287: 50-61

11. Rieux-Laucat F, Magerus-Chatinet A, Neven B. The Autoimmune Lymphoproliferative Syndrome with Defective FAS or FAS-Ligand Functions. J Clin Immunol. 2018; 38: 558-68.

12. Kantarcı OH, Hebrink DD, Achenback SJ, et al. CD95 polymorphisms are associated with susceptibility to MS in women. A populationbased study of CD95 and CD95L in MS. J Neuroimmunol. 2004; 146: 162-70.

13. Huang QR, Danis V, Lassere M, Edmonds J, Manolios N. Evaluation of a new Apo-1/Fas promoter polymorphism in rheumatoid arthritis and systemic lupus erythematosus patients. Rheumatology. 1999; 38: 645-51.

14. Fisher GH, Rosenberg FJ, Straus SE, et al. Dominant interfering fas gene mutations impair apoptosis in a human autoimmune lymphoproliferative syndrome. Cell. 1995; 81: 935-46.

15. Takahashi T, Tanaka M, Inazawa J, et al. Human Fas ligand: gene structure, chromosomal location and species specificity. Int Immunol. 1994; 6: 1567-74.

16. Huang QR, Morris D, Manolios N. Identification and characterization of polymorphisms in the promoter region of the human Apo-1/Fas (CD95) gene. Mol Immunol. 1997; 34: 577-82.

17. Sibley K, Rollinson S, Allan JM, et al. Functional FAS promoter polymorphisms are associated with increased risk of acute myeloid leukemia. Cancer Res. 2003; 63 432: 7-30.
18. Kanemitsu S, Ihara K, Saifddin A, et al. A functional polymorphism in Fas (CD95/AP0-1) gene promoter associated with systemic lupus erythematosus. J Rheumatol. 2002; 29: 1183-8.

19. Wu J, Metz C, Xu X, et al. A novel polymorphic CAAT/enhancer-binding protein element in the FasL gene promoter alters Fas ligand expression: a candidate background gene in African American systemic lupus erythematosus patients. J Immunol. 2003; 170: 132-8.

20. van Veen T, Kalkers NF, Crusius JBA, et al. The FAS-670 polymorphism influences susceptibility to multiple sclerosis. J Neuroimmunol. 2002; 128: 95-100.

21. Huang QR, Teutsch SM, Buhler MM et al. Evaluation of the apo-1/Fas promoter mva I polymorphism in multiple sclerosis. Mult Scler. 2000; 6: 14-18.

22. Niino M, Kikuchi S, Fukazawa T, et al. An examination of the Apo-1/Fas promoter Mva I polymorphism in Japanese patients with multiple sclerosis. BMC Neurol. 2002; 2: 8.

23. Mohammadzadeh A, Pourfathollah AA, Sahraian MA, et al. Evaluation of apoptosisrelated genes: Fas (CD94), FasL (CD178) and TRAIL polymorphisms in Iranian multiple sclerosis patients. J Neurol Sci. 2012; 312: 16669.

24. Kaminska J, Koper OM, Piechal K, Kemona H. Multiple sclerosis- etiology and diagnostic potential. Postepy Hig Med Dosw. 2017; 71: 551-63.

25. Sakai T, Inoue A, Koh CS, Osame M. Serum levels of apoptosis-related molecules in patients with multiple sclerosis and human $\mathrm{T}$ lymphotropic virus Type I-associated myelopathy. J Interferon Cytokine Res. 1999; 19: 999-1004. 
26. Zipp F, Weller M, Calabresi PA, et al. Increased serum levels of soluble CD95 (APO-1/ Fas) in relapsing-remitting multiple sclerosis. Annals of Neurology. 1998; 43: 116-120.

27. Moreno M, Saenz-Cuesta M, Castillo J, et al. Circulating levels of soluble apoptosis-related molecules in patient with multiple sclerosis. J Neuroimmunol. 2013; 263: 152-4.
28. Ciusani E. Frigerio s, Gelati M, et al. Soluble Fas (Apo-1) levels in cerebrospinal fluid of multiple sclerosis patients. J Neuroimmunol. 1998; 82: 5-12. 